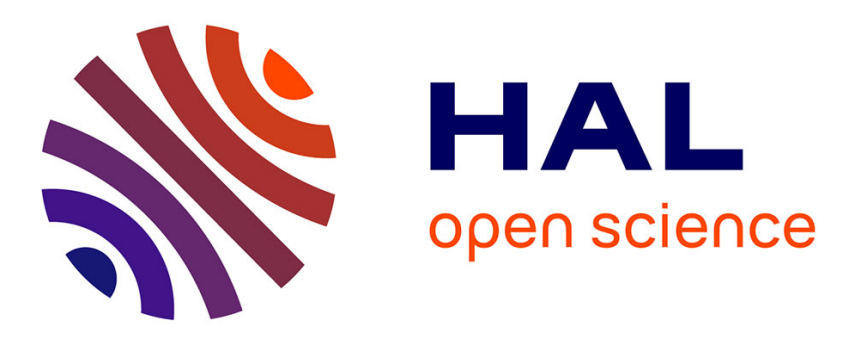

\title{
Evaluation of Non-Rigid Registration Techniques for Region of Interest Propagation in Adaptive Radiation Therapy
}

A. Franz, S. Allaire, Mallya Y., Buerger C., Kabus S., H. P. Bijl, Schulz H., Bzdusek K.

\section{To cite this version:}

A. Franz,, S. Allaire,, Mallya Y., Buerger C., Kabus S., et al.. Evaluation of Non-Rigid Registration Techniques for Region of Interest Propagation in Adaptive Radiation Therapy. 2013 American Association of Physicists in Medicine (AAPM) Annual Meeting, Aug 2013, Indianapolis, United States. pp.SU-E-J-68, 10.1118/1.4814280 . hal-01016666

\section{HAL Id: hal-01016666 https://hal.science/hal-01016666}

Submitted on 30 Sep 2014

HAL is a multi-disciplinary open access archive for the deposit and dissemination of scientific research documents, whether they are published or not. The documents may come from teaching and research institutions in France or abroad, or from public or private research centers.
L'archive ouverte pluridisciplinaire HAL, est destinée au dépôt et à la diffusion de documents scientifiques de niveau recherche, publiés ou non, émanant des établissements d'enseignement et de recherche français ou étrangers, des laboratoires publics ou privés. 
A Franz, S Allaire, Y Mallya, C Buerger, S Kabus, HP Bijl, H Schulz and K Bzdusek, 'Evaluation of Non-Rigid Registration Techniques for Region of Interest Propagation in Adaptive Radiation Therapy', abstract SU-E-J-68 in proceedings of the AAPM annual meeting, 4-8 August 2013, Indianapolis, in Medical Physics 40, 165 (2013). http://dx.doi.org/10.1118/1.4814280

\section{Evaluation of Non-Rigid Registration Techniques for Region of Interest Propagation in Adaptive} Radiation Therapy

A Franz ${ }^{1}$, S Allaire ${ }^{2}$, Y Mallya ${ }^{3}$, C Buerger ${ }^{1}$, S Kabus ${ }^{1}$, HP Bijl $^{4}$, H Schulz $^{1}$ and K Bzdusek ${ }^{5}$

${ }^{1}$ Philips Research, Hamburg, Germany

${ }^{2}$ Philips Research, Suresnes, France

${ }^{3}$ Philips Electronics Pvt Ltd, Bangalore, India

${ }^{4}$ University Medical Center, Groningen, Netherlands

${ }^{5}$ Philips Healthcare, Fitchburg, WI

Purpose: Adaptive radiation therapy aims at compensating anatomical variations during a radiotherapy course by modifying the treatment plan accordingly. Therefore regions of interest (ROIs) have to be defined in the most recent imaging data. We investigated three different non-rigid image registration algorithms to automatically propagate ROIs from an initial planning CT to a pre-treatment CT. Methods: Clinical reference data of four patients with head and neck tumor, consisting of a planning CT and a pre-treatment CT, were used in this study. Seven ROIs (spinal cord, glottis, left and right parotid glands, left and right submandibular glands and thyroid) were independently delineated by three head and neck radiation oncologists in the initial planning CT as well as in the pre-treatment CT. The ROIs defined in the planning CT were automatically propagated to the pre-treatment CT using three different non-rigid registration algorithms: salient-feature-based registration, piecewise linear registration, and elastic registration, based on partial differential equations. The propagated ROIs were quantitatively compared with the expert-drawn ROIs. As measures for comparison the Dice coefficient for the whole 3D region, the mean slicewise Dice coefficient and the mean slicewise Hausdorff distance were used. Results: All three registration algorithms were able to propagate the investigated structures such that they deviate from the hand-segmented contours in a range comparable with the inter-observer variability, ranging up to $15 \mathrm{~mm}$ mean slicewise Hausdorff distance and down to a Dice coefficient of 0.5. The deviations are smaller when the propagated structures are compared with the reference structures recontoured by the same physician. Conclusion: Different image registration algorithms were compared for its use in adaptive radiation therapy. All three methods yielded acceptable results. However, automatically propagated ROls should be thoroughly reviewed by the treating physician. The remaining deviations from the expert-drawn ROIs can be corrected by interactive tools. 